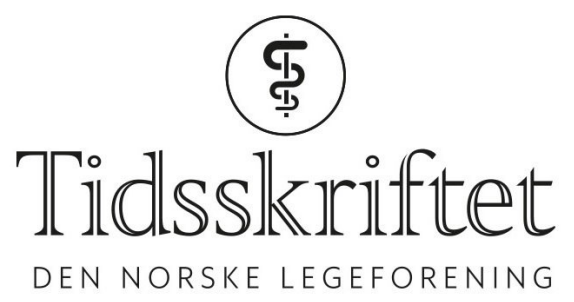

\title{
Representative pasientutvalg er unødvendig i klinisk forskning
}

\author{
DEBATT \\ EIVIND SCHJELDERUP SKARPSNO \\ E-post: eivind.s.skarpsno@ntnu.no \\ Eivind Schjelderup Skarpsno er stipendiat ved ph.d.-programmet medisin og helsevitenskap ved \\ Institutt for samfunnsmedisin og sykepleie, Norges teknisk-naturvitenskapelige universitet. Han \\ underviser blant annet i epidemiologi og forskningsmetode og er representant for den nasjonale \\ forskerskolen i populasjonsbasert epidemiologi (EPINOR). \\ Forfatter har fylt ut ICMJE-skjemaet og oppgir ingen interessekonflikter.
}

Ikke-representative pasientutvalg - i motsetning til heterogene, representative utvalg - er avgjørende for studiers validitet.

Ofte leser jeg at man bør bruke representative utvalg i randomiserte kliniske studier, dvs. heterogene pasientutvalg som representerer fordelingen av de ulike personkarakteristikkene som man finner i pasientpopulasjonen, fordi det vil øke den ytre validiteten (1). Men hvem er egentlig funnene gyldige for? Representative pasientutvalg er selvfølgelig av betydning hvis man skal utføre meningsmålinger blant pasienter eller avdekke hvor mange som har en viss type sykdom. Når det gjelder å besvare kliniske forskningsspørsmål, er saken en annen. Én enkelt studie kan ikke brukes for å fastslå om effekten er gyldig for andre utvalg og under andre betingelser enn det man har undersøkt for i studien. For eksempel er det ikke sikkert at pre- og postmenopausale kvinner, unge og eldre menn har samme effekt av en tenkt behandling. Hormonelle påvirkninger, ulik sykdomshistorikk og alvorlighetsgrad, genetiske forskjeller og ulik komorbiditet spiller inn. I klinisk forskning må inklusjonskriterier være strenge, slik at alle disse forstyrrende faktorene holdes konstant. Med andre ord tilstreber man en mest mulig homogen gruppe med høy indre validitet. Altså: et ikke-representativt pasientutvalg.

La oss anta at vi ønsker å teste en ny type sykdomsdempende medisin blant pasienter med ankyloserende spondylitt, en kronisk revmatisk sykdom som typisk rammer leddene i ryggraden og bekkenet. La oss anta at pasientgruppen er svært homogen, for eksempel hvite, norske postmenopausale kvinner i alderen 50-55 år som ikke bruker andre medisiner, fikk diagnostisert sykdommen i samme alder, har hatt samme sykdomsforløp, like konsentrasjoner av ulike biomarkører, ingen komorbide sykdommer, samme fysiske aktivitetsnivå og samme utdanningsnivå. Kanskje vil man tro at disse strenge inklusjonskriteriene svekker de eventuelle funnene fordi resultatene ikke er gyldige for andre pasientgrupper. Det er en begrensning at funnene ikke nødvendigvis er gyldige for andre pasientgrupper, men bruk av et representativt pasientutvalg vil ikke løse dette. Tvert imot. La oss si at vi inkluderte kvinner og menn i alle aldre, med variasjon i etnisitet, medisinbruk, biomarkører, komorbide sykdommer, fysisk aktivitetsnivå og 
sosioøkonomisk status - med andre ord et representativt utvalg som representerer alle undergruppene i pasientpopulasjonen. Behandlingseffekten er da ikke nødvendigvis gyldig for hele pasientpopulasjonen, men vil være en gjennomsnittlig effekt som er vektet av behandlingseffekten i de ulike undergruppene. Så lenge utvalget er for lite til at man kan stratifisere på forstyrrende faktorer, har man faktisk ingen informasjon om mulige undergrupper som kan respondere ulikt på behandlingen. Hvis man ønsker å teste om den sykdomsdempende medisinen er effektiv for andre pasienter, så må det gjøres spesifikt på disse pasientene. Det er en forenkling å tro at dette kan løses i én enkelt studie som består av et representativt pasientutvalg.

\section{Strenge inklusjonskriterier, høy indre validitet}

Målet med klinisk forskning bør være å produsere resultater som vi vet er gyldige for de pasientene vi studerer. Ved å ha strenge inklusjonskriterier som holder alle forstyrrende faktorer konstant, kan vi være rimelig sikre på at resultatene faktisk er gyldige for den pasientgruppen vi studerer. Ikke-representative pasientutvalg er derfor helt avgjørende for å sikre troverdige resultater som kan brukes på best mulig måte i klinisk praksis. Det er nemlig summen av gode studier med høy indre validitet som gir riktig kunnskap om pasientene i populasjonen.

LITTERATUR:

1. Kennedy-Martin T, Curtis S, Faries D et al. A literature review on the representativeness of randomized controlled trial samples and implications for the external validity of trial results. Trials 2015; 16: 495. [PubMed][CrossRef]

Publisert: 21. februar 2019. Tidsskr Nor Legeforen. DOI: 10.4045/tidsskr.19.0047

Mottatt 15.1.2019, godkjent 23.1.2019.

(C) Tidsskrift for Den norske legeforening 2020. Lastet ned fra tidsskriftet.no 